\title{
МІЖКУЛЬТУРНА ДІЛОВА КОМУНІКАЦІЯ У ПРОФЕСІЙНІЙ ПІДГОТОВЦІ МАЙБУТНІХ ФАХІВЦІВ: СУЧАСНИЙ ВИМІР І ТЕНДЕНЦІЇ РОЗВИТКУ
}

\author{
Гнезділова С. П. \\ кандидат наук з державного управління, \\ стариий викладач кафедри украӥнознавства \\ Національний університет «Одеська морська академія» \\ м. Одеса, Украӥна
}

Існування міжкультурної ділової комунікації, як явища соціокультурного, в сучасних умовах піддається значним трансформаційним перетворенням, що пов'язано з посиленням впливу процесів загальної глобалізації, у тому числі й поширенням інформаційної глобалізації. Вимогою часу стала мобільність, необхідність швидкого отримання будь-якої інформації, мультикультурне сприйняття світових викликів і проблем, що поступово призводить до нівелювання інформаційних кордонів. Сучасна міжкультурна комунікація набуває рис прагматичного цілеспрямованого використання комунікативної парадигми, а також акцентована на інтелектуальній та інформаційній діяльності.

Проте, інформаційні потоки безупинно наповнюють простір та потребують генерування, опору, відсіювання непотрібного, i головне критичного осмислення інформації. Отже, для зрозумілої та ефективної комунікації $є$ важливим набуття навичок критичного мислення. Уміння критично сприймати будь-яку інформацію дозволяє ефективно використовувати комунікативні засоби у міжкультурній діловій комунікації: змістовно і впевнено користуватися пошуковими системами, мережами, онлайн застосунками, виділяти головне, ключові слова і фрази, швидко орієнтуватися у словниковому діловому полі.

Реагуючи на вимоги сьогодення, міжкультурна комунікація має бути когерентною та забезпечувати розвиток у різних галузях діяльності. Спілкуючись різними мовами, представники культур повинні, перш за все, ставитися один до одного, як до партнерів, з довірою, знаходити порозуміння, будувати злагоджену роботу, приймати спільні рішення. При цьому, процес міжкультурної комунікації вимагає взаємного сприйняття та узгодження національних самобутніх культурних особливостей націй у міжкультурному управлінні процесами діяльності для отримання спільних результатів. 
Досягнення міжкультурної комунікації - актуальне питання сьогодення і сучасний виклик міжнародному розвиткові. Міжкультурна комунікація є важливою для укладання ділових угод за участі представників різних культур у багатьох галузях. На теперішній час актуальною $є$ тенденція гармонізації галузей діяльності міжнародного співтовариства, злагодженості та переходу на єдині світові професійні стандарти, що потребує узгодження між країнами. Одним 3 основних трендів успішності у світовому суспільстві стає професіоналізація. Сучасні суспільно-економічні зміни, інтеграція між країнами зумовлюють підготовку конкуретноспроможних фахівців.

Наприклад, підготовка майбутніх фахівців морської галузі безпосередньо стосується міжнародного судноплавства, як складової міжнародної морської індустрії, отже, питання міжкультурної комунікації тут $є$ основоположним. Прохід суден через порти різних країн, багатонаціональний характер екіпажів, суперечливий і конкурентний характер взаємодії інтересів судноплавства - фактори, що вимагають взаєморозуміння та співпраці на міжнародному рівні. Опанування професійною та мовленнєвою культурою є необхідними умовами професійної підготовки фахівців морської галузі. Ефективність міжкультурної комунікації залежить від мовної компетенції фахівців як складової професійної компетентності.

До факторів, що мають значний вплив на ефективність міжкультурної ділової комунікації, слід віднести наступні: володіння мовними ресурсами, мовною та мовленнєвою компетенцією, мовленнєвою культурою, культурою ділового мовлення. Ці фактори формують мовну, мовленнєву та комунікативну компетентності у майбутніх спеціалістів. Мовні ресурси $-\epsilon$ засобами, які найкраще відповідають комунікації за певних умов і можуть використовуватись фахівцем за необхідності. Мова, матеріалізуючи картини світу відповідно до свідомості та оригінального мислення і світосприйняття у професійній діяльності, адаптується до відповідної мовної компетенції. Мовна компетенція грунтується на знанні базових понять, внутрішній потребі володіти професійною мовою, розумінні зображувально-виражальних особливостей мови, умінні проводити навчально-пізнавальну та аналітичну діяльність, а також доцільності використання мовних засобів у практичній діяльності та умінні встановлювати контакти залежно від комунікативних ситуацій. Володіння мовленнєвою комунікативною компетенцією $є$ основною характеристикою професійно підготовленого фахівця, спроможного встановити ділову комунікацію, вирішити будь-яке питання, прийняти управлінське рішення. 
Мовленнєва культура формується відповідно до специфіки профілю навчання у вищих навчальних закладах, де майбутні фахівці набувають фахових знань, умінь, навичок та досвіду (зокрема, під час проходження практики), активного спілкування за професійним спрямуванням як рідною, так і іноземними мовами. Знання мов професійного спрямування збагачує професійну культуру. На теперішній час інформаційна доступність ресурсів, спілкування «без кордонів» 3 представниками різних світових культур, у тому числі й за допомогою соціальних мереж, оновлення та поповнення міжкультурної фахової інформації в онлайн режимі дають змогу отримувати мовні та професійні знання, розширюють діловий тезаурус, підвищують професійну культуру.

Культура ділового мовлення $є$ засобом ділового мислення й управління професійною поведінкою, важливою рисою компетентного персоналу, який володіє ключовими навичками для ефективної роботи в міжнародних компаніях, зокрема, умінням вести ділові перемовини, будувати ефективні комунікації тощо. Сучасною тенденцією професійної компетентності стає крос-культурна компетентність та крос-культурна комунікація за участю різних країн або культур (від англ. cross-cultural involving two or more different cultures and their ideas and customs) [5]. Так, українська дослідниця Пальчикова О. розглядає поняття кроскультурної компетентності, як «здатність побачити спільне в культурах країн» [2, с. 320], а для «формування крос-культурної компетентності, особистісні якості, культурна обізнаність, суб'єктна взаємодія стають дедалі важливішими, аніж просто знання мови» [2, с. 321]. Галузеве різноманіття ділової практики засвідчує відмінності професійних етик, що пов'язано зі специфікою професій. У підготовці фахівців морської галузі Токарева О. зауважує на активізації вміння слухати інших учасників взаємодії, виробничого процесу (членів команди судна), і в результаті аналізу власної діяльності та діяльності членів команди приймати правильне рішення, особливо в критичних ситуаціях, характерних для довготривалих рейсів у різномовних за складом екіпажах $[4$, с. 125]. 3 метою досягнення позитивної міжкультурної комунікації у ділових професійних стосунках міжкультурного простору вироблені універсальні міжнародні правила ділового спілкування, які полягають: у взаємній повазі; використанні правдивої інформації 3 метою підвищення рівня довіри між колегами; встановленні довірливих стосунків, що виявляються під час надання професійної допомоги, підтримки; дотриманні принципу доцільності у професійних відносинах (умінні знаходити ефективні рішення для розв'язання складних питань); чіткому й переконливому висловленні думок та ін. [3, с. 140]. Таким 
чином, основою культури ділового мовлення стає опанування та професійне володіння міжмовною комунікацією, що пов'язане з глибинним вивченням мов і потребує інтегративного підходу до різних культур.

Міжкультурна ділова комунікація на теперішній час перебуває у стані стрімкого оновлення та пошуку інноваційних підходів щодо професійної гнучкості у підготовці майбутніх фахівців до глобалізаційних змін, що потребує підвищення рівня знань, умінь, з урахуванням спільних змін у культурних i ментальних установках людства, переформатування у тенденціях світового розвитку та використання можливостей міжкультурних комунікацій для створення міцної культурної основи та подальшої великомасштабної співпраці.

\section{Література:}

1. Ерін Маєр. Культурна карта. Бар'єри міжкультурного спілкування в бізнесі. Наш формат, 2020. 224 с.

2. Пальчикова О.О. Крос-культурна компетентність у навчанні української мови як іноземної, 2012. Методика викладання мов. Філологічні студї. вип. 8. С. 319-326.

3. Сайтарпи І.А. Культура міжособистісних стосунків : навч. посібник. К: Академвидав. 240 с.

4. Токарева О. Сучасні підходи у формуванні мовленнєвої культури майбутніх фахівців морської галузі в умовах вищого навчального закладу. Педагогічні науки : зб.наук.nр. вип. LX XVII. Том 2, 2017. C. 122-126.

5. Cambridge dictionary. URL: https://dictionary.cambridge.org/ru/ словарь/английский/cross-cultural (дата звернення: 05.07.2021) 